Please quote as: Peters, C. \& Menschner, P. (2012): Towards a Typology for Telemedical Services. In: Ancilliary Proceedings of the 20th European Conference on Information Systems (ECIS), Barcelona, Spain. 


\title{
TOWARDS A TYPOLOGY FOR TELEMEDICAL SERVICES
}

\author{
Peters, Christoph, Information Systems, Kassel University, Pfannkuchstr. 1, 34121 \\ Kassel, christoph.peters@uni-kassel.de
}

Menschner, Philipp, Information Systems, Kassel University, Pfannkuchstr. 1, 34121

Kassel, menschner@uni-kassel.de

\begin{abstract}
This research-in-progress (RIP) paper presents a typology for describing and classifying telemedical services (TMS). As TMS are highly heterogeneous and complex, our objective is to provide an overview of TMS and to reduce the complexity of handling the highly distinctive TMS. Our typology is based on 13 well-described dimensions (e.g. purpose), each represented by a set of attributes (e.g. cure, palliation, prevention or rehabilitation). Based on this, we want to enable a representation of a highly aggregated overview of the TMS domain that fosters understandability and systematic differentiation of TMS in this interdisciplinary domain. We show that the few existing telemedicine typologies fall short of this purpose. Thus, we adjust and extend these typologies in order to present a new typology that suits the current demands. In this paper, we already show the typology's applicability in real world scenarios. We thereby contribute by fostering manageability of this complex field for all participants of TMS. This can help with the identification of both well-established structural patterns and best practices of existing TMS, setting a basis for benchmarking opportunities. Further it allows the identification of interesting and promising white spots for future research and service innovations in the telemedicine sector.
\end{abstract}

Keywords: telemedicine, typology, service system, eHealth. 


\section{Motivation and Research Approach}

Telemedicine services (TMS) are defined as the provision of medical services over geographic distances through the use of information and communication technology (DGTelemed 2011). As the demographic shift in many industrialized countries has led to increased health care spending and a higher demand for services, threatening existing public health and welfare systems, TMS have the potential to overcome many of the prevailing difficulties. Yet, the global telemedicine market is expected to grow from $\$ 9.8$ billion in 2010 to $\$ 23$ billion in 2015 (BCC Research 2011), representing a fast growing market. This paper's contribution is to provide a comprehensive typology that allows structuring and describing TMS.

Typologies are "conceptual, multidimensional classification schemes or sets of configurations that have been derived without a formally collected and quantitatively analyzed data set. [They identify] configurations or types exclusively on the basis of conceptual or theoretical distinctions" and resultant typologies are of an "a priori nature and generated mentally and verbally, not by any replicable empirical basis" (Bailey 1994). These characteristics make typologies distinctively different from other classifications such as taxonomies, which are explicitly based on empirical data (Bailey 1994). Existing typologies for TMS (Dierks 1999; Dardelet 2001; Schultz and Salomo 2005) integrate valuable considerations, but they fall short on providing a decent description and classification scheme. The goals of our typology can be described as descriptive and classificatory (Elman 2005). We thereby outline the characteristic features of TMS on the one hand and provide classification opportunities on the other hand. The descriptive function of the typology is represented by 13 welldescribed dimensions, each represented by a set of attributes. While the dimensions claim to comprise the overall TMS environment and define a complete TMS typology, the attributes do not claim to be exhaustive. This is an important characteristic of our typology since it allows smaller adaption due to technical advancements, etc. Also, it might even inform new TMS configurations. Whereas the descriptive function of our typology is important and presents the TMS environment at a glance, the main contribution lies in its classificatory goals. Through the classification, the typology helps to structure the TMS environment, which is characterized by the heterogeneity of both TMS and its service system participants, as well as by the diversity of the involved application fields and domains. We test our typology's applicability by using exemplary TMS. We plan to extend this testing by using numerous TMS from various origins in consecutive research. Thereby, we provide benchmarking opportunities and allow for the derivation of meta or reference classes for TMS. Meta classes would increase manageability, because the heterogeneity of TMS could be separated into homogeneous classes that share common features. The dimensions' derivation was based on conceptual and theoretical distinctions as per definition. We considered the existent knowledge base and the results of our literature search as a valuable starting point. We include references for all dimensions that are derived based on the according sources. The remaining dimensions are derived conceptually and from our own experience which is based on interviews with different participants of the service system telemedicine, own development of TMS and the conduction of several case studies within the TMS environment.

\section{The TMS Typology}

This section presents our newly developed telemedicine typology which aims to overcome the shortcomings of the existing ones. The set of dimensions is described in Table 1. For each dimension, we present a description including a set of attributes which is not a final set and explicitly allows the combination of attributes and the co-existence of more than one attribute per dimension within a TMS. The two right columns of the table apply the typology using two example TMS. The first TMS is a defibrillator 24/7 telemonitoring service including alarm functionality (TMS 1), the other TMS provides hospitals with highly specialized doc-2-doc teleconsultation support for stroke units (TMS 2). 


\begin{tabular}{|c|c|c|c|}
\hline Dimension & Dimension's Description & TMS 1 & TMS 2 \\
\hline Purpose & $\begin{array}{l}\text { TMS can follow different purposes such as cure, palliation, prevention or } \\
\text { rehabilitation. }\end{array}$ & Curative & Curative \\
\hline $\begin{array}{l}\text { Application } \\
\text { field }\end{array}$ & $\begin{array}{l}\text { This can be any sort of medical field such as cardiology, radiology, surgery, } \\
\text { psychiatry, etc. Thereby, the before-mentioned combination of attributes } \\
\text { within one dimension is important. There are TMS that address several } \\
\text { fields of application at the same time, e.g. devices measuring different vital } \\
\text { parameters at a glance and require different skill sets, e.g. manual aptitude } \\
\text { in surgery in contrast to emotional intelligence for psychiatric treatments. }\end{array}$ & Cardiology & Neurology \\
\hline $\begin{array}{l}\text { Involved } \\
\text { participants }\end{array}$ & $\begin{array}{l}\text { TMS are characterized by its heterogeneous stakeholders such as patients } \\
\text { and their relatives, physicians and clinical personnel, (IT) service providers } \\
\text { and professionals, hospitals and health insurance companies (Peters, Drees } \\
\text { et al. 2011). The overall telemedical environment can be regarded as a } \\
\text { service system which is defined as "a value-creation network composed of } \\
\text { people, technology, and organizations" (Maglio, Srinivasan et al. 2006). }\end{array}$ & $\begin{array}{l}\text { Patients, } \\
\text { physicians, (IT) } \\
\text { service providers }\end{array}$ & $\begin{array}{l}\text { Patients, } \\
\text { physicians, clinic } \\
\text { personnel, (IT) } \\
\text { service providers, } \\
\text { hospitals }\end{array}$ \\
\hline Paying entity & $\begin{array}{l}\text { Within TMS, the target user (patient / physician) might not be the paying } \\
\text { entity (for doc-2-patient / doc-2-doc settings). Instead, health insurance } \\
\text { companies are often responsible for the financial funding of offered patient- } \\
\text { TMS. This is the case in the primary health market. In contrast, the } \\
\text { secondary health market is characterized by private funding. A special case } \\
\text { is the provision of TMS that have an initial funding from research funding } \\
\text { institutions for a clearly defined pilot phase. }\end{array}$ & $\begin{array}{l}\text { Statutory health } \\
\text { insurance }\end{array}$ & $\begin{array}{l}\text { Statutory health } \\
\text { insurance, } \\
\text { ministries, one } \\
\text { NPO, one private } \\
\text { company }\end{array}$ \\
\hline $\begin{array}{l}\text { Business } \\
\text { model }\end{array}$ & $\begin{array}{l}\text { The aspect of the business model of TMS relates to the decision of the TMS } \\
\text { payment structure. Often the costs for telemonitoring TMS at the patient's } \\
\text { home can be characterized through initial device costs at the beginning of } \\
\text { the overall treatment process and concurrent costs throughout the treatment } \\
\text { phase. The design of the payment structure is an important decision for the } \\
\text { service provider and might differ considerably depending on the decision } \\
\text { whether to sell or rent the device. }\end{array}$ & $\begin{array}{l}\text { Initial device / } \\
\text { implementation } \\
\text { payment plus } \\
\text { regular } \\
\text { monitoring } \\
\text { payments }\end{array}$ & $\begin{array}{l}\text { Payments per } \\
\text { session }\end{array}$ \\
\hline $\begin{array}{l}\text { Information } \\
\text { type }\end{array}$ & $\begin{array}{l}\text { As all service systems, the TMS use or create information, which in the } \\
\text { context of service systems "can be expressed as informational entities that } \\
\text { are used, created, captured, transmitted, stored, retrieved, manipulated, } \\
\text { updated, displayed, and/or deleted by processes and activities" (Alter 2011). } \\
\text { Typical types could be: voice or video (doc-2-doc consultation), electronic } \\
\text { data sets (e.g. vital data and used sensors), observed emotions (psychiatric } \\
\text { consulting hour) or self-reported documents (nutrition monitoring). The } \\
\text { type of information has an influence on its accuracy and unambiguousness. }\end{array}$ & $\begin{array}{l}\text { Sensor-captured } \\
\text { electronic data }\end{array}$ & $\begin{array}{l}\text { Video, sensor- } \\
\text { captured } \\
\text { electronic data }\end{array}$ \\
\hline $\begin{array}{l}\text { Technology } \\
\text { type }\end{array}$ & $\begin{array}{l}\text { TMS integrate ICT per definition. The interplay of technology-enabled and } \\
\text { person-oriented service activities is highly relevant for TMS as } \\
\text { "[telemedical] service systems are decomposed into successively smaller } \\
\text { subsystems, some of which are totally automated" (Alter 2011). }\end{array}$ & $\begin{array}{l}\text { Sensors, data } \\
\text { station, fixed line } \\
\text { connection }\end{array}$ & $\begin{array}{l}\text { Camera, medical } \\
\text { equipment, fixed } \\
\text { line connection }\end{array}$ \\
\hline Frequency & $\begin{array}{l}\text { The treatment's frequency can be either discrete or continuous and might } \\
\text { vary from once in a lifetime, e.g. for discrete alarm functionalities, to a } 24 / 7 \\
\text { continuous telemonitoring setting. }\end{array}$ & Continuous & Discrete \\
\hline Synchrony & $\begin{array}{l}\text { The delivery of a telemedicine service can be synchronically, which } \\
\text { indicates that the communicating participants have to invest in coordination } \\
\text { activities so that the communication / interacting can be guaranteed. } \\
\text { Asynchronous service delivery means that the communication process does } \\
\text { not require the presence of the participants at the same time. }\end{array}$ & Asynchronous & Synchronous \\
\hline Criticality & $\begin{array}{l}\text { Criticality describes a responsiveness requirement. It addresses the variance } \\
\text { for availability and reaction demands, e.g. between the control of weight } \\
\text { development for obesity patients versus life-critical TMS in stroke unit } \\
\text { networks. }\end{array}$ & $\begin{array}{l}\text { Immediate action } \\
\text { required }\end{array}$ & $\begin{array}{l}\text { Immediate action } \\
\text { required }\end{array}$ \\
\hline Location & $\begin{array}{l}\text { The place of the service consumption is the direct environment of the TMS } \\
\text { location setting. It might range from the location of the medical service } \\
\text { provider, e.g. hospitals, to the direct environment of the patient, i.e. his or } \\
\text { her home or workplace, to extremely challenging settings such as airline } \\
\text { flights or very remote areas. }\end{array}$ & At home & Hospital \\
\hline $\begin{array}{l}\text { (Device) } \\
\text { mobility }\end{array}$ & $\begin{array}{l}\text { Many TMS are enabled through the use of devices which vary in terms of } \\
\text { portability. While telemedical defibrillators are implemented, other devices } \\
\text { have to be worn. Others are at least portable - either restricted for specific } \\
\text { areas such as the patient's home or completely location-independent - and } \\
\text { TMS might be stationary as well (e.g. doc-2-doc TMS in hospitals). }\end{array}$ & $\begin{array}{l}\text { Implemented } \\
\text { (monit. only } \\
\text { within data station } \\
\text { boundaries) }\end{array}$ & Static \\
\hline $\begin{array}{l}\text { Process } \\
\text { orientation }\end{array}$ & $\begin{array}{l}\text { TMS consist of service activities and processes. When activities have a } \\
\text { clear sequence and individual steps that are performed using defined } \\
\text { methods, they constitute a process (Alter 2011). Levels of process } \\
\text { orientation might range from no process orientation to modular process } \\
\text { designs characterized by clearly defined process units and interfaces. }\end{array}$ & $\begin{array}{l}\text { Strong (automated } \\
\text { monitoring and } \\
\text { escalation } \\
\text { process) }\end{array}$ & $\begin{array}{l}\text { None (one } \\
\text { consulting activity } \\
\text { on demand) }\end{array}$ \\
\hline
\end{tabular}

Table 1: Typology's dimensions and application 


\section{Discussion and Conclusion}

This paper faces some limitations. Although the descriptive character of our typology could be shown through the application of four example TMS, more TMS are needed to confirm our typology's classificatory claim. We will continue to describe and classify TMS, and, by the time of the conference, we hope to be able to present first meta classes and best-practice TMS. Further, this paper misses a detailed evaluation of the presented typology. This will be achieved during the continuous data collection and application of the typology. We contribute by the provision of a typology that consists of 13 dimensions and allows structuring and describing TMS. For each dimension, we outline a set of attributes. Through its descriptive character, the typology can be used as navigation aid and entry point for practitioners and scientists that are new to the field of TMS. From the perspective of its classificatory goal, the typology enables the detection and development of meta or reference classes of different TMS which allows the identification of best practices, success stories and thus providing a basis for comparison or benchmarking and increase manageability of the heterogeneous TMS environment. Thereby, we address the needs of TMS experts who search for structured differentiation of their objects of investigation. With the typology, we articulate a cohesive view of relevant dimensions that are usually discussed separately and are dealt differently in the various application fields and domains. We hence try to create a basis of shared information and jointly used language and terminology for the very heterogeneous field of TMS. Thus, we also contribute by facilitating interdisciplinary TMS developments and service innovation. Future research needs to show that our typology meets the intended goals to derive meta and reference classes for TMS, to help with the identification of white spots and to support benchmarking and business opportunities.

\section{Literature}

Alter, S. (2011). Metamodel for Service Design and Service Innovation: Integrating Service Activities, Service Systems, and Value Constellations. ICIS 2011

Bailey, K. D. (1994). Typologies and taxonomies: An introduction to classification techniques. Thousand Oaks, California, USA, Sage Publications, Inc.

BCC Research. (2011). "Research Report Telemedicine: Opportunities for Medical and Electronic Providers." Retrieved 17.03.2011, 2011, from http://www.bccresearch.com/report/HLC014D.html.

Dardelet, B. (2001). In the kingdom of expertness, the profane is king. Carriers of medical innovations. Proceedings of the 34th Annual Hawaii International Conference on System Sciences, Maui, Hawaii, USA.

DGTelemed. (2011). "Telemedizin." Retrieved 17.03.2011, 2011, from http://www.dgtelemed.de/de/telemedizin/.

Dierks, C. (1999). "Rechtliche und praktische Probleme der Integration von Telemedizin in das Gesundheitswesen in Deutschland." Retrieved 19.09.2011, 2011, from http://edoc.huberlin.de/habilitationen/medizin/dierks-christian/PDF/Dierks.pdf.

Elman, C. (2005). "Explanatory Typologies in Qualitative Studies of International Politics." International Organization 59(2): 293-326.

Maglio, P. P., S. Srinivasan, et al. (2006). "Service systems, service scientists, SSME, and innovation." Communications of the ACM 49(7): 81-85.

Peters, C., A. Drees, et al. (2011). Productivity of Telemedical Services - A State of the Art Analysis of Input and Output Factors. Proceedings of XXI International RESER Conference, Hamburg, Germany.

Schultz, C. and S. Salomo (2005). Systematik und Eigenschaften telemedizinischer Dienstleistungen. Akzeptanz der Telemedizin. C. Schultz, H. G. Gemünden and S. Salomo. Darmstadt, Germany, Minerva KG: 36 . 